なれて位置すれば常に遠心力の作用にさらされる事に なるので,これは将来航空医学や宇宙旅行の医学的研 究の一環として，必要な装置となる事も考元られる.

\section{4. 視性眼振の検查}

廻転室の外部に塗った黄と紫の絴縞を利用して; 視 性眼振の㭘查を行うことができる。この検査は，耳科 眼科のみならす，中枢神経疾患の或種のものの診断上 にも役立つと云水れる。

\section{V. 総 括}

近代的迷路機能検查法の要氺を満すための一つの装 置として，2 馬力の三相交流整流子電動機を主動力と し, その㻁転速度を小型直流操作用電動機でコントロ ールし, 更に平蔽車及びウォーム:ギヤーで減速して 廻転室の角速度を $50 \sim 180^{\circ} / \mathrm{sec}$., 角加速度を $03^{\circ} \sim 10^{\circ}$ /sec.の間で連続的に調整し得る装置を試作して使用

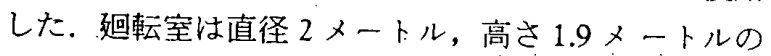
円筒型で，内部には交流電源をスリップリングを介し て導入し, 被検者の他飞各種検查器具, 記録装置及び 検者をも乗せたま子廻転するから，迴転停止後の所謂 クプログラムのみならず, 廻転中の諸現象も観察し得 る. 停止は電磁ブレーキにより，そのバネの強さを加 隇して, 停止時間 $1 \sim 2$ 秒とした。 上記の各性能につ いては実測により検定吟味して，実用の市能なことを 確かめた。

本装置は本邦最初のものであり, 迷路機能検査以外 にも, 迷路自律神経反射, 動摇病(のりものよい)の 研究, 航空医学, 視性眼振検查等に利用できるもので あるから，今後も大いにこれを活用して，その研究成 績を夫々の尃門誌に報告する予定で岀る。

（本研究は，昭和29, 30年度, 文部省科学試験研究
費の補助により行われたもので㘯る)

\section{参考 文 献}

1) Bárány R. (1907) Monatschrift f. Ohrenheilk. 51, 173.

2) Buys E. \& Rijlant P. (1939) Arch. Int. Physiol. $49,101$.

3) Fisher M. H. (1923) Ergebn. Physıol. 27, 209.

4) Tönnies J. F. (1931-32) Zeitschr. f. Hals-usw Heilk. 30, 535.

5) Groen J. J. \& Jongkees L. B. W. (1949) J. La. ryng. \& Otol $62,231-235$.

6) Hallpike C. S. et al. (1952) Acta oto-laryng. 42, 511-538.

7) Békésy G. (1955) Arch. Otolatyng. (Chicago) 61, 16-28.

8) Montandon A. et Russbach A. (1955) Pract. oto-rhino-laryng. 17, 224.

9) Mittermeier R. und Rossberg G. (1956) Arch. Ohr-usw. Heilk. und Zeitschr. Hals-sw. Heilk. (1956) 168, 313-332.

10) Wüst H. (1956) Arch. Ohr-usw. Heilk. und Zeitschr. Hals-usw. Heilk. 168, 414-428.

11) van Egmond et al. (1953) International Course in Vestibular Examination, Utrecht. Druk kerij, Schotanus \& Jens.

12) Ashan G. et al. (1953) Acta oro-laryng. 43, 22 26.

13) Schierbeek P. (1953) Practica oto-rhino-larvngol. 15, 73.

14) Arslan M. (1954) Ann. d'oto-laryng. (paris) $71,113-122$.

15) Rossberg G. et al. (1955) Zeitschrift f. Laryng., Rhiolog. und Otologie 34, 376-381.

16) Montandon A. et al. (1955) Annals of otol., Rhinol. \& Laryngol. 64, 701-717.

\section{「ふぐ」恐るるに足らず}

「ふぐは喰いたし，命は惜しし」といわれるくら い,「ふぐ」は，味としては上々なるので，昔から下 関の名物として，名が通っており，今日では，大抵の 土地で食べられる：ところが，調理法か悪いと，ひど い中毒を起す盧れがあるところから，恐怖心にかられ て，食わず嫌いの人が，可なり多い。

近頃は, 調理法も研究され, 衛生上の監督も受け一 いるので, 別段恐机る必要は少しもない。「ふぐ」に は,テトロドキシンといら毒素が, 卵巣や肝臓に方っ て，産卵期には一層毒が劇しくなるので，むしこわい と思ったら，この期を避ければよい。

種類でいうと，最も毒の強いのが「あかめふぶくと 呼ばれるもので，体の表面に，大きな斑絞があり，小 さな沢山の斑紋がこれを取巻いていて，棘を持ってい

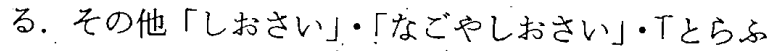

ぐ」なども，毒が劇しく，「まふぐ」は毒性が稍々薄 く，全く無毒なのは，「よりとふぐ」といわれるもの である。また部分についていうと, 雌の卵巣, 俗に 真子といわれるむのに毒が多く，之れに次いで肝蔵， また血液にも，多少の毒性を持っているが，筋肉には 殆ぞ毒性がない: 雄の白子には毒性はあるけれど, 極 く薄く, 雄で毒の強いのは肝臟である。

季節でいうと，三月から五月までの間，即ち産卵期 で, その頃になると, 卵巣が非常に肥大して, 平素の 数倍になり，毒性が強烈になる。五月頃が最も劇し い：中毒を避けようとするには第一に産卵期でないこ と, それから真子や肝臟の有毒部を完全に除き，庖丁 を骨に当てないようにして調理し，水でよく洗って， 血液を去り，単に肉ばかり食べるようにすれば決して 間違いはない，最も安心なのは「よりとふぐ」を用い ればよい。 